\title{
EVALUASI PENGGUNAAN KAMERA NON METRIK PADA FOTOGRAMETRI JARAK DEKAT
}

\author{
Dimas Ricky Pratama, Teguh Hariyanto \\ Program Studi Teknik Geomatika FTSP-ITS, Kampus ITS Sukolilo, Surabaya, 60111 \\ Email :
}

\begin{abstract}
Abstrak
Citra yang ideal adalah citra yang merepresentasikan obyek secara sempurna tanpa terjadi degradasi kualitas. Namun tidak ada lensa yang dapat memnuhi hal tersebut. Kemampuan lensa dikatakan maksimum apabila sebuah lensa mereproduksi citra dari sebuah obyek hingga mencapai titik di mana detail citra sudah tidak dapat lagi direproduksi dari obyek. MTF (modulation transfer function) diukur sebagai patokan kemampuan lensa untuk membedakan antara daerah gelap dan terang pada obyek. Standar optik untuk pengukuran MTF menggunakan unit frekuensi spasial disebut "line pair per millimeter" atau lp/mm. Dengan mengetahui nilai MTF, sebuah citra dengan degradasi kualitas dapat ditingkatkan kualitasnya.
\end{abstract}

Kecerahan merupakan salah satu faktor penting dalam hasil MTF. Peningkatan kontras dengan meningkatkan perbedaan kecerahan antara obyek dan latar belakang benda dapat memberikan perbedaan informasi yang didapat. Manipulasi kontras dilakukan sebagai peregangan kontras dengan meningkatkan perbedaan kecerahan yang seragam di seluruh dynamic range dari citra. Dari informasi MTF suatu lensa dan perubahan nilai kontras dengan teknik contrast stretching akan menghasilkan sebuah citra dengan peningkatan kualitas sehingga interpretasi citra tersebut lebih fleksibel untuk menghasilkan informasi yang dibutuhkan.

Sebuah citra digital harusnya memiliki tingkat kecerahan yang optimum yaitu mulai dari gelap sampai terang. Hal tersebut ditandai dengan nilai digital number citra yang memiliki range $0-225$. Dari hasil penelitian penggunaan kamera Canon Powershot A2200 menunjukkan perubahan digital number pada citra hasil perekaman yang sebelumnya memiliki rentang 10 - 255 untuk band merah dan biru menjadi 0 - 255 pada semua band dengan peningkatan nilai mean untuk tiap - tiap band : Red(115.2 menjadi 127.1), Green(111.4 menjadi 126.9) dan Blue(93.9 menjadi 129.5). Peningkatan nilai digital number tersebut menunjukkan bahwa adanya peningkatan kecerahan dari citra sebelumnya sehingga daerah yang sebelumnya gelap menjadi relatif terang.

Kata Kunci: MTF, kecerahan, Contrast Stretching, digital number, band

\section{PENDAHULUAN}

\section{Latar Belakang}

Pada bidang fotogrametri, penggunaan kamera masih didominasi oleh kamera metrik analog yang harganya mahal. Hal tersebut dikarenakan dalam fotogrametri terutama dalam kebutuhan pemetaan, ketelitian geometrik dan intepretasi rona menjadi alasan utama. Sekarang ini teknologi kamera yang semakin berkembang menjanjikan penggu-naannya yang lebih luas. Dimulai dari kamera analog hingga digital dengan fitur yang canggih, penggunaan kamera menjadi lebih fleksibel untuk berbagai kepentingan.

Dengan perkembangan yang semakin maju telah membuka peluang foto udara dengan kamera jenis ini. Terlebih penggunaan kamera non metrik dalam Close Range Photogrammetry.
Fotogrametri jarak dekat (Close-range photogrammetry) didefinisikan sebagai fotogrametri dengan pengambilan foto/citra pada jarak kurang dari $300 \mathrm{~m}$ dari objek atau permukaan bumi. (J. R. Williamson, 2007).

Teknik tersebut memiliki kelebihan terutama jika objek yang akan diukur sulit untuk dijangkau dan atau memiliki dimensi yang kecil. Selain itu, teknik ini memerlukan biaya yang relatif murah bila dibandingkan dengan fotogrametri jarak jauh karena jenis kamera yang digunakan adalah kamera non metrik yang merupakan kamera yang tidak didesain untuk keperluan pemotretan udara / pemotretan geometri. Oleh karena itu, penelitian ini dimaksudkan untuk meneliti ketajaman hasil foto kamera digital murah dengan menganalisa tingkat kecerahan (contrast level) 
sehingga dapat memadai untuk kepentingan fotogrametri jarak dekat.

\section{Rumusan Permasalahan}

Dari uraian diatas permasalahan yang dihadapi adalah memperoleh informasi mengenai nilai histogram RGB band dan tingkat kecerahan sebelum dan sesudah adanya citra restoration and enhancement.

\section{Batasan Masalah/Ruang Lingkup}

Adapun batasan masalah dalam penelitian ini adalah sebagai berikut:

1. Wilayah studi adalah daerah Jurusan Teknik Geomatika ITS, Surabaya.

2. Data yang digunakan adalah foto udara dari kamera non metrik dijital dengan sensor CCD (Powershot A2200).

3. Penelitian dilakukan dengan menggu-nakan wahana aeromodelling tanpa gyro (alat level kamera).

4. Ketinggian terbang kurang dari $300 \mathrm{~m}$.

5. Metode yang digunakan dalam penajaman citra adalah metode gaussian, median filtering, bicubic resampling.

\section{Tujuan}

Tujuan penulisan penelitian ini adalah :

1. Melakukan analisis untuk mengetahui apakah foto hasil kamera non metrik digital dapat digunakan untuk fotogrametri jarak dekat dari segi tingkat resolusi.

2. Melakukan analisis pola histogram tingkat kecerahan foto hasil pemotretan.

\section{Manfaat}

1. Mengetahui kemampuan lensa kamera Canon Powershot A2200.

2. Mengetahui nilai histogram citra sebelum dan sesudah citra hasil restoration dan citra hasil enhancement.

3. Mendapatkan informasi nilai digital number citra sebelum dan sesudah restorasi citra maupun penajaman citra.

4. Memberikan suatu informasi mengenai kemampuan kamera non metrik digital terutama dari segi tingkat kecerahannya sebagai alternatif foto udara berbiaya murah.

\section{METODOLOGI PENELITIAN}

\section{Lokasi Penelitian}

Lokasi penelitian ini dilakukan di Kabupaten Pacitan, Propinsi Jawa Timur paling selatan

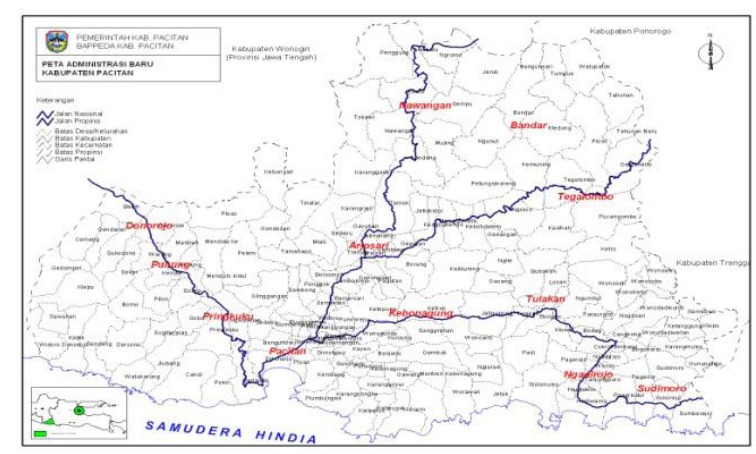

Gambar 1. Lokasi Penelitian(Bappeda Pacitan, 2008)

\section{Data Dan Peralatan}

- Data

Data yang digunakan dalam penelitian ini adalah:

1. Data foto udara (aerial) diambil dengan kamera non metrik dari wahana terbang dengan ketinggian $<300 \mathrm{~m}$.

2. Data foto chart pattern (USAF-1951 bar target).

\section{- Peralatan}

Peralatan yang digunakan dalam penelitian ini adalah:

1. Perangkat Keras (Hardware)

a. 1 unit Notebook

b. Printer Canon MP 2800

c. Kamera digital :

- Canon Power Shot A2200 HD

- Effective pixel 14.1 megapixel

- Sensor size : 1/2.3" (6.17 x 4.55 $\mathrm{mm}$ )

- Sensor type : CCD

d. Wahana Aero Modeling

2. Perangkat Lunak (Software)
a. ENVI 4.8
b. QuickMTF 2.0
c. ERMapper 7.1 


\section{Diagram Alir Pengolahan Data}

Adapun untuk diagram alir pengolahan data adalah sebagai berikut:

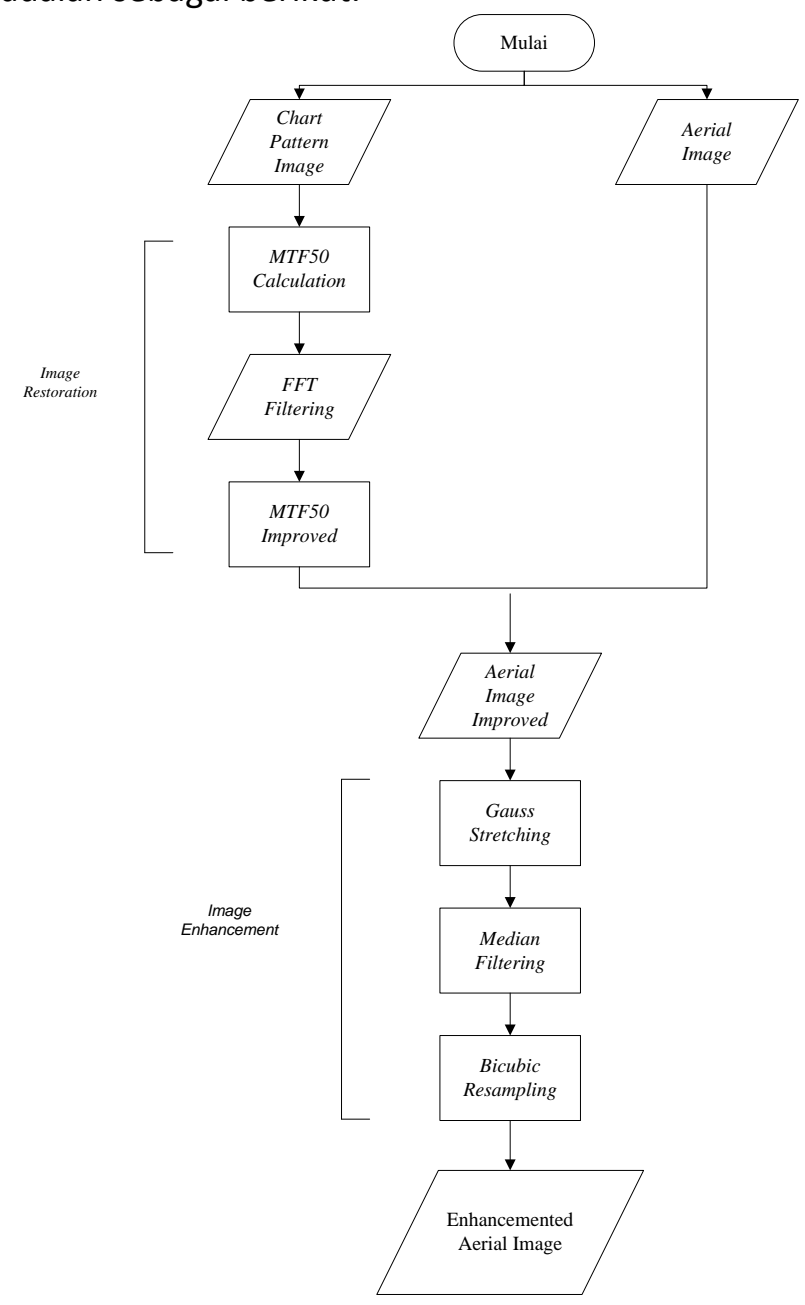

Gambar 2. Diagram Alir Pengolahan Data

Berikut ini adalah penjelasan diagram alir tahap pengolahan data:

- Calibration Chart dan Citra foto udara

Pada tahap ini dilakukan pengambilan dua macam data yaitu:

- Data Calibration Chart

Data ini merupakan citra hasil perekaman chart kalibrasi oleh kamera Canon PowerShot A2200 menggunakan bar target USAF-1951.

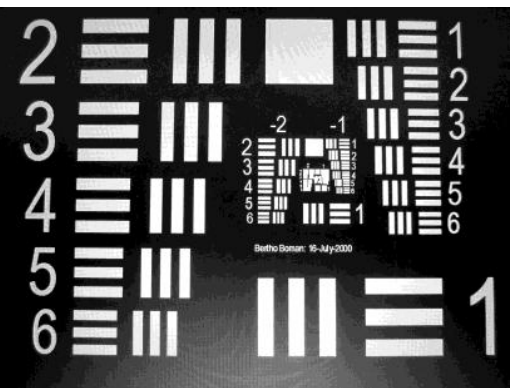

Gambar 3. Citra Calibration Chart (USAF-1951)

Fstop $\quad: f / 2.8$

Eksposure time : $1 / 60 \mathrm{~s}$

ISO Speed : :ISO-320

Focal Lenght $\quad: 5 \mathrm{~mm}$

Resolusi (Pixel) : $4320 \times 3420$

- Data Citra foto udara

Merupakan data foto udara yang diambil oleh kamera PowerShot A220 menggunakan wahana aeromodelling tipe horizontal flight tanpa gyro.

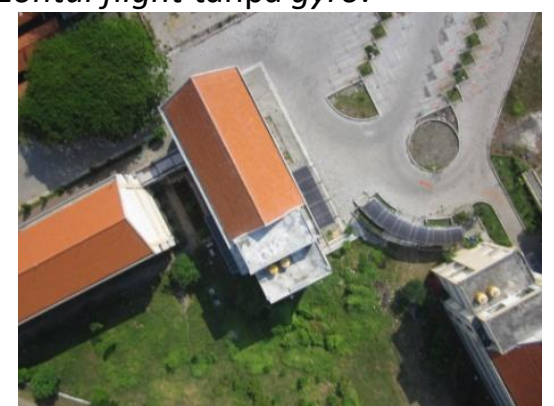

Gambar 4. Citra foto udara

$\begin{array}{ll}\text { F stop } & : f / 2.8 \\ \text { Eksposure time } & : 1 / 1000 \mathrm{~s} \\ \text { ISO Speed } & : 150-80 \\ \text { Focal Lenght } & : 5 \mathrm{~mm} \\ \text { Resolusi (Pixel) } & : 4320 \times 3420\end{array}$

- Image Restoration

Tahap ini meliputi penggunaan Fourier Filtering pada citra yang telah terukur nilai MTF50. Nilai MTF50 adalah nilai modulasi citra yang kontrasnya turun $50 \%$. Kontras yang turun sampai $50 \%$ merupakan kontras yang ideal untuk membedakan terang dan gelap pada sebuah citra.

a. MTF50 Calculation

Nilai MTF50 didapat dari pengolahan citra chart pattern menggu-nakan software Quick MTF 2.0.

b. FFT Filtering Chart 
Setelah didapat nilai MTF50 selanjutnya dila-kukan FFT Filtering. Koreksi ini dilakukan pada citra difungsikan untuk membuat perbaikan kurva MTF citra. Metode Fourier Transform digu-nakan karena metode ini merupakan invers MTF terhadap PTF (point transfer function).

c. MTF50 Improved

Setelah melalui proses filter maka akan terlihat besaran modulasi yang berubah dan selanjutnya nilai tersebut dioverlay ke citra foto udara.

- Image Enhancement

a. Gaussian Stretching

Dilakukan contrast stretching dengan metode gaussian. Hal ini dimaksudkan agar nilai histogram RGB band pada citra menjadi sesuai distribusi normal/gauss.

b. Noise Removing

Dilakukan penghilangan noise pada citra dengan mengganti nilai DN pixel noise menjadi DN rata - rata pada sekeliling noise. Hal tersebut dilakukan menggunakan metode median filtering. Metode ini akan merubah nilai pixel di sekitar noise bernilai median di antara pixel tersebut.

c. Resampling

Resampling adalah pembuatan pixel baru untuk memperbaiki gambar akibat resizing, hingga tampilan gambar menjadi lebih baik. Terdapat beberapa metode diantaranya billinear dan bicubic. Billinear merupakan metode yang mengacu pada 4 pixel yang berada di dekatnya, di bagian atas, bawah, kiri, dan kanan. Sedangkan bicubic, prinsip kerjanya sama dengan billinear namun metode resampling yang digunakan mengacu pada 16 pixel yang terdapat di sekitar pixel yang akan dibuat.

- Enhancemented Image

Setelah proses restorasi dan penajaman gambar. Hasil gambar akan dianalisa.

\section{ANALISA}

\section{Hasil R (Line Per Mm) dan Mtf}

Dari hasil proses pengolahan didapatkan data sebagai berikut :

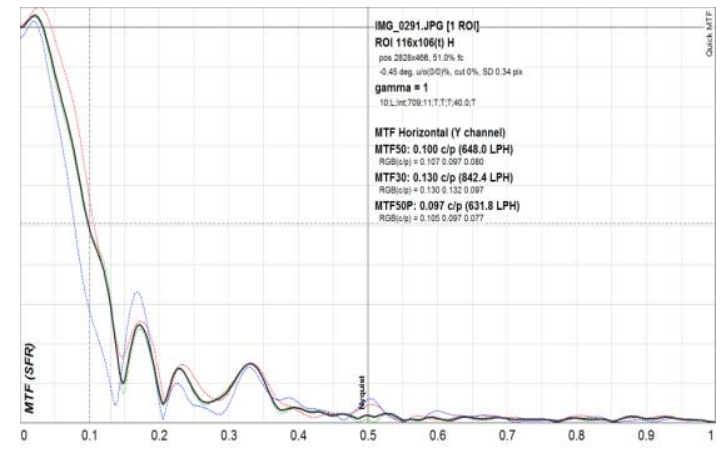

Gambar 5. Nilai MTF sebelum FFT

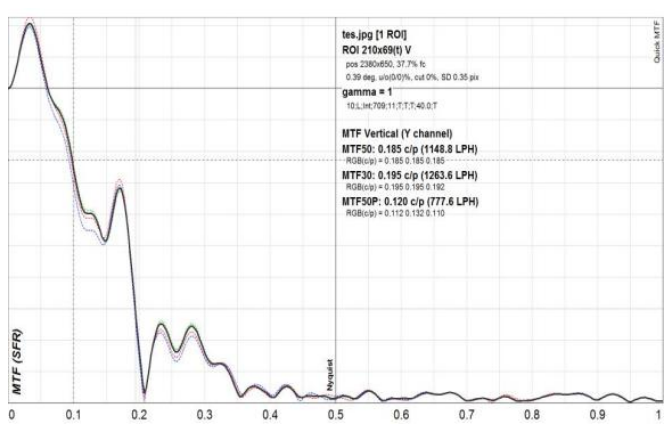

Gambar 6. Nilai MTF setelah FFT

Dalam gambar di atas terlihat nilai modul RGB (garis - garis berwarna) mengalami sedikit simpangan dari nilai modulation (garis hitam) yang berarti bahwa radiometrik kamera yang digunakan memiliki sedikit simpangan dari warna sebenarnya. Untuk nilai modulation dihasilkan resolusi MTF50 : 0,100 c/p (648 LPH). Hal tersebut berarti pada kecerahan yang turun $50 \%$ nilai resolusi yang didapatkan adalah $0,100 \mathrm{cycle} /$ pixel atau setara dengan $70,2 \mathrm{lp} / \mathrm{mm}$.

Setelah dilakukan penggunaan fourier transformation pada citra, dan dilakukan pengukuran MTF ulang, maka didapatkan resolusi MTF50 : 0,185 c/p (1198 LPH) yang berarti resolusi bernilai $0,185 \mathrm{c} / \mathrm{p}$ atau setara dengan 129 $\mathrm{lp} / \mathrm{mm}$.

Sedangkan dalam pengukuran melalui rumus $\mathrm{R}=$ $\frac{1}{2 \times p}$ dengan $\mathrm{R}$ adalah line pair per $\mathrm{mm}$ dan $\mathrm{p}$ adalah pixel pitch, didapatkan hasil resolusi sebesar 350,8 $\mathrm{lp} / \mathrm{mm}$. Hasil tersebut merupakan 
hasil resolusi yang ideal untuk kamera dengan sensor berukuran 1/2,3" $(6,17 \times 4,5 \mathrm{~mm})$.

Hasil resolusi awal sebesar 70,2 Ip/mm merupakan hasil yang cukup jauh dari resolusi ideal sebesar 350,8 $\mathrm{lp} / \mathrm{mm}$. Dengan penggunaan fourier transformation, dapat meningkatkan hasil resolusi citra sebesar $129 \mathrm{lp} / \mathrm{mm}$.

\section{Analisa Citra foto udara Setelah FFT Filtering}

Berikut adalah perbandingan citra sebelum dan sesudah FFT Filtering.

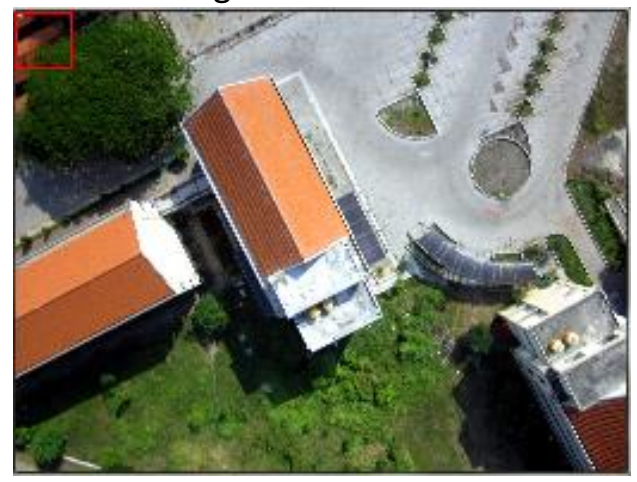

Gambar 7. Citra sebelum FFT

Tabel 1. Statistik band pada citra sebelum FFT

\begin{tabular}{cccc} 
Basic Stats & Min & Max & Mean \\
\hline Band 1 & 10 & 255 & 115.196979 \\
& & & \\
Band 2 & 10 & 255 & 111.434236
\end{tabular}

Band $3 \quad 0 \quad 255 \quad 93.898575$

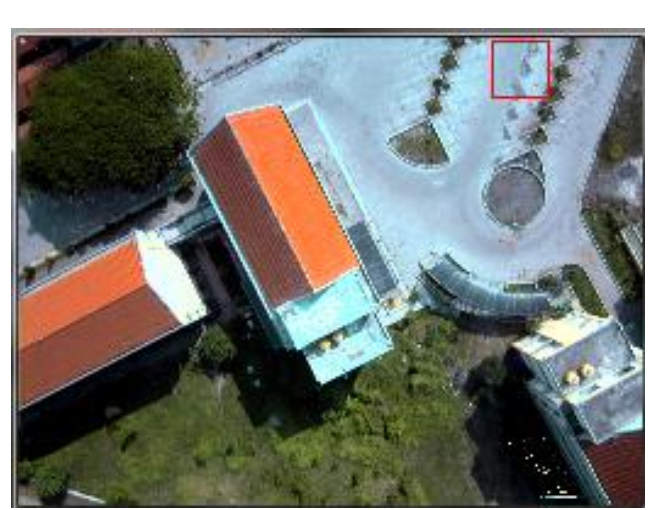

Gambar 8. Citra setelah FFT
Tabel 2. Statistik band pada citra setelah FFT

\begin{tabular}{cccc}
\hline Basic Stats & Min & Max & Mean \\
\hline Band 1 & 0 & 255 & 102.639111 \\
Band 2 & 0 & 255 & 105.930294 \\
Band 3 & 0 & 255 & 99.853564 \\
\hline
\end{tabular}

Berdasarkan tabel 2, nilai min-max pada band 1-3 bernilai $0-255$, hal tersebut menandakan bahwa nilai radiometrik band telah terkoreksi dari hasil sebelumnya.

\section{Analisis Contrast Level Dengan Metode Gaussian Stretching}

Berikut hasil citra setelah melalui proses gaussian stretching.

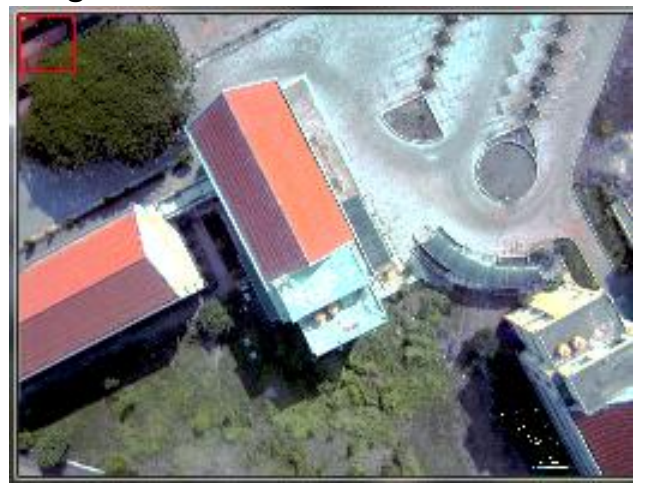

Gambar 9. Citra setelah Stretching Gauss

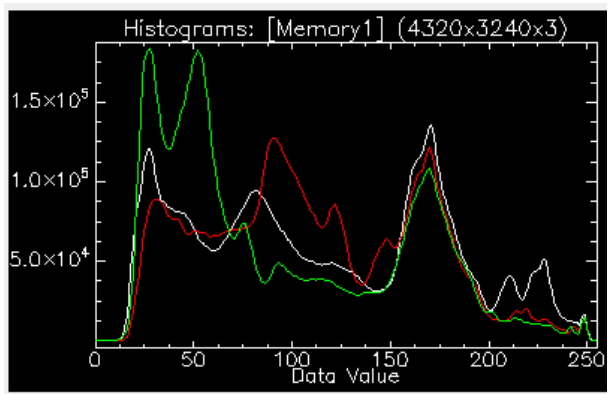

Gambar 10. Histogram Citra sebelum Stretching Gauss

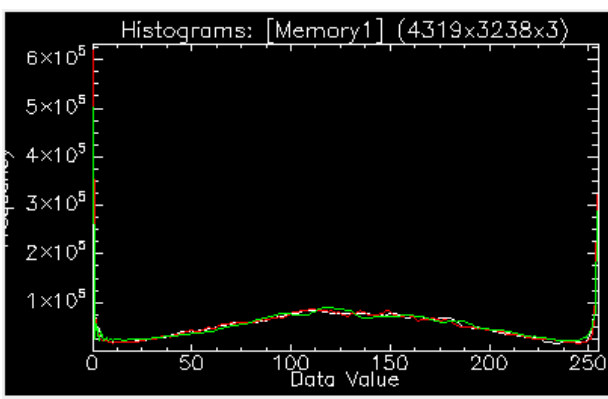

Gambar 11. Histogram Citra setelah Stretching Gauss 
Tabel 3. Statistik band pada citra setelah Gaussian Stretching

\begin{tabular}{cccc} 
Basic Stats & Min & Max & Mean \\
\hline Band 1 & 0 & 255 & 127.11118 \\
Band 2 & 0 & 255 & 126.95095 \\
& & & \\
Band 3 & 0 & 255 & 129.56001
\end{tabular}

Sebagaimana ditunjukkan oleh tabel dan citra di atas, terdapat perubahan nilai mean pada tiap band yang cenderung membesar nilai digital numbernya. Hal tersebut menunjukkan adanya peningkatan kecerahan pada citra dengan nilai digital number yang semakin membesar. Terlihat pada hasil citra bahwa di daerah bayangan gedung memiliki kecerahan yang lebih cerah bila dibandingkan dengan citra sebelumnya. Dan juga dapat terlihat pada vegetasi yang lebih cerah sehingga dapat dibedakan antara vegetasi rimbun dan tidak.

\section{Analisis Noise Removal Dengan Metode Median Filtering}

Dari proses median filtering menunjukkan perbandingan noise pada citra seperti pada gambar 12 dan gambar 13 dengan nilai kernel $5 \mathrm{x}$ 5.

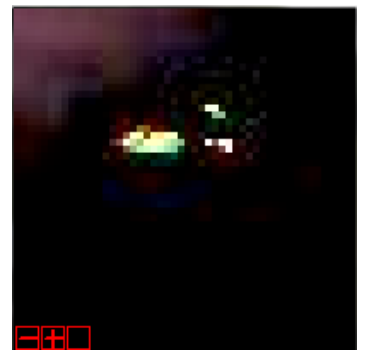

Gambar 12. Noise Citra sebelum Median Filtering

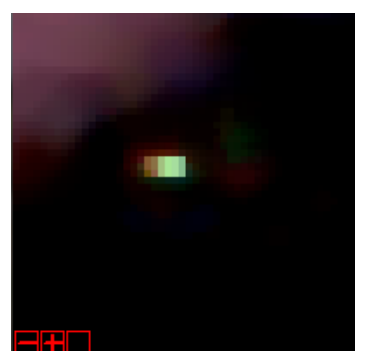

Gambar 13. Noise Citra setelah Median Filtering
Tabel 4. Statistik band pada citra setelah Median Filtering

\begin{tabular}{cccc}
\hline Basic Stats & Min & Max & Mean \\
\hline Band 1 & 0 & 255 & 127.04968 \\
Band 2 & 0 & 255 & 126.88616 \\
& & & \\
Band 3 & 0 & 255 & 129.50744 \\
& & &
\end{tabular}

Pada citra 12 terlihat bahwa adanya reduksi noise yang cukup berarti dengan nilai statistik yang tidak terlalu berubah. Hal ini berarti bahwa removal noise tidak merubah nilai mean digital number secara signifikan sehingga nilai kecerahan citra tetap terjaga.

\section{Analisis Smoothing Dengan Metode Bicubic Resampling}

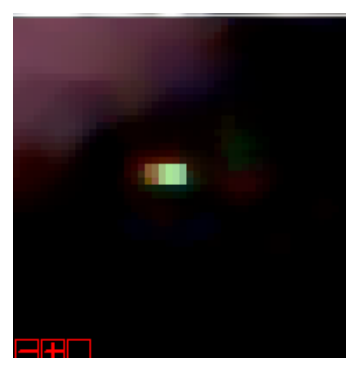

Gambar 14. Citra Sebelum resampling

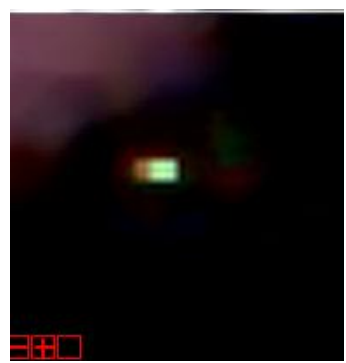

Gambar 15. Citra Sebelum resampling

Dengan metode bicubic resampling, akan ada penghalusan pixel dengan membuat pixel baru. Pembuatan pixel mengacu pada 16 pixel yang berada di dekatnya. Dari warna pixel tersebut kemudian ditentukan pixel baru dengan warna yang merupakan warna campuran dari pixel sebelumnya.

Hal tersebut akan membuat citra terlihat lebih halus bila dibandingkan sebelumnya. 


\section{Citra Hasil Penajaman}

Dari citra hasil penajaman terlihat adanya peningkatan kecerahan pada bayangan gedung, sehingga vegetasi yang tertutup bayangan relatif lebih terlihat.

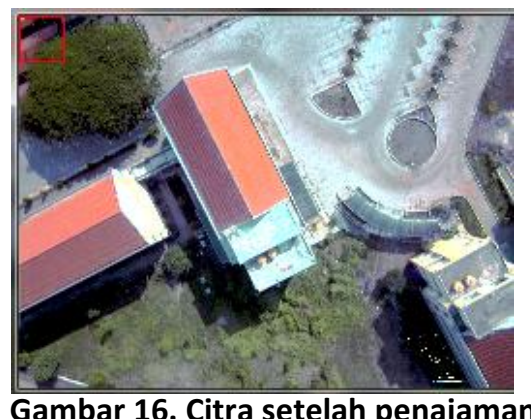

Dan juga pada paving parkiran terlihat adanya pola daerah yang menunjukkan bahwa daerah tersebut memiliki permukaan yang berbeda.

Pada perbandingan citra 8 bit (grayscale) citra hasil enhancement, terlihat beberapa hasil bergantung pada band yang digunakan.

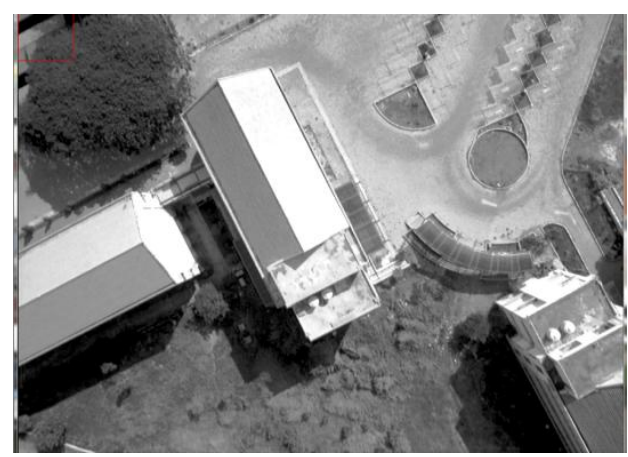

Gambar 17. Citra hasil enhancement dengan display grayscale pada band merah

Untuk band merah terlihat berpengaruh pada area yang tertimpa cahaya matahari. Pada area yang tertimpa cahaya matahari langsung akan meningkat kontrasnya.

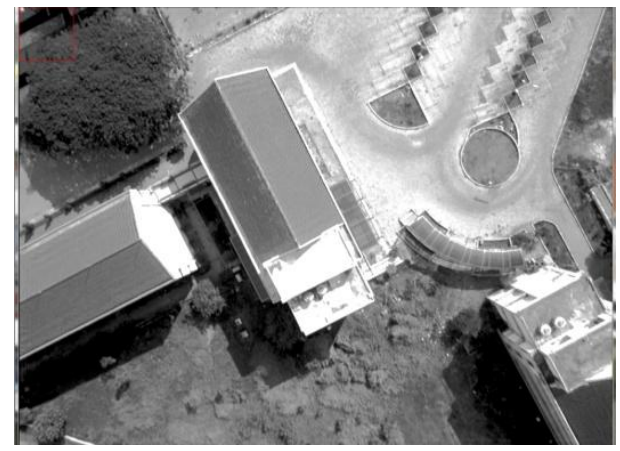

Gambar 18. Citra hasil enhancement dengan display grayscale pada band hijau

Untuk band hijau terlihat berpengaruh pada pola jalan yang berpasir dan vegetasi. Pada area tersebut detil citra terlihat meningkat.

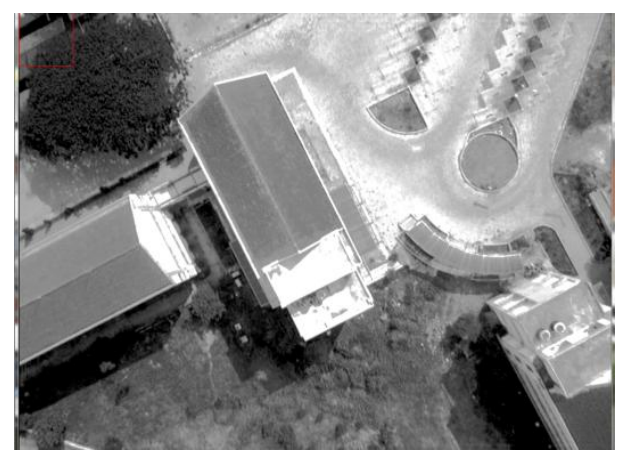

Gambar 19. Citra hasil enhancement dengan display grayscale pada band biru

Untuk band biru terlihat adanya penigkatan detil pada area dengan bayang - bayang gedung bila dibandingkan dengan band yang lain. Perbandingan tersebut menunjukkan bahwa tiap band memiliki karakteristik tersendiri dalam proses radiometrik.

Untuk visualisasi lebih lanjut, dapat dilakukan pembandingan dengan konversi band RGB menjadi HSV (hue-saturation-value) dan HSL (huesaturation-lightneess). Hasilnya dapat dilihat pada gambar berikut. 


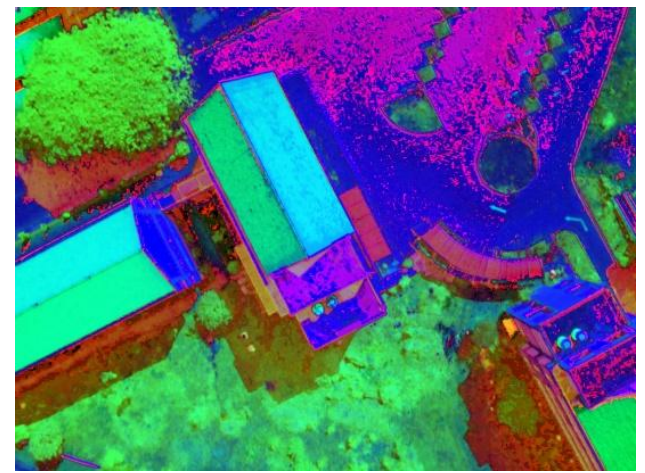

Gambar 20. Citra awal dengan transformasi warna RGB ke HSV

Pada transformasi warna citra dari RGB menjadi HSV terlihat adanya pengelompokan pixel warna yang terdekat. Dengan membandingkan antara citra awal dan citra enhancement pada pola warna HSV, dapat terlihat perbedaan signifikan antara permukaan area parkir dan atap bangunan. Area parkir pada gambar 3.15 terlihat tidak memiliki permukaan yang jelas dan batas area parkir mobil tidak terlihat, berbeda halnya dengan gambar 21.

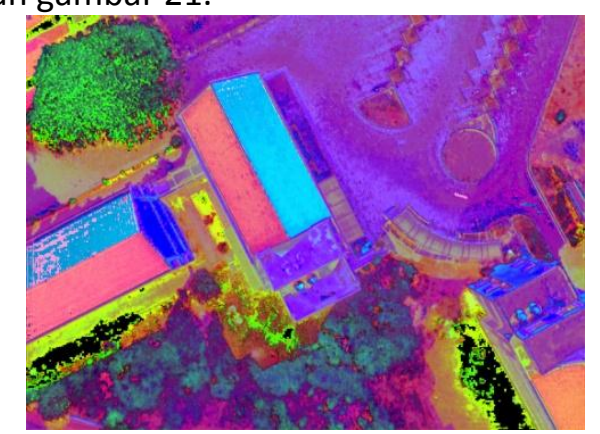

Gambar 22. Citra hasil enhancement dengan transformasi warna RGB ke HSV

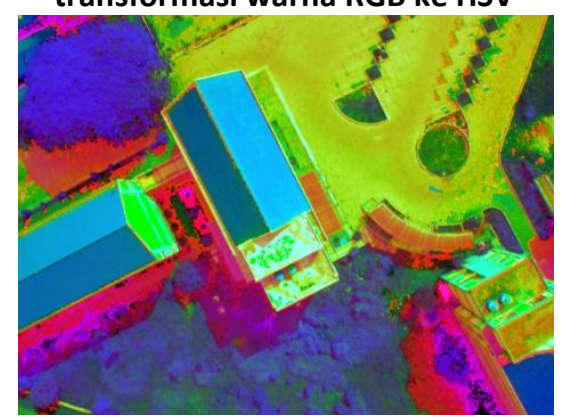

Gambar 23. Citra awal dengan transformasi warna RGB ke HSL

Dengan transformasi warna dari RGB ke HSL akan memiliki informasi lebih padadetil batas (edge) pada obyek di citra. Hal itu terlihat pada area bayang - bayang.

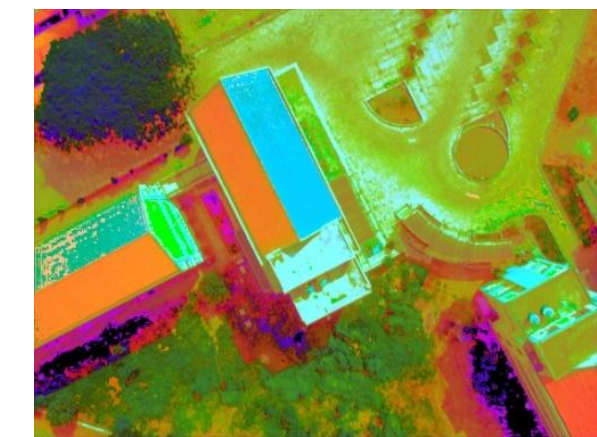

Gambar 24. Citra hasil enhancement dengan transformasi warna RGB ke HSL

Pada citra dengan transformasi warna dari RGB ke HSL memiliki karakteristik peningkatan visual pada area bayangan obyek, hal tersebut dapat dilihat pada gambar 23 dan 24.

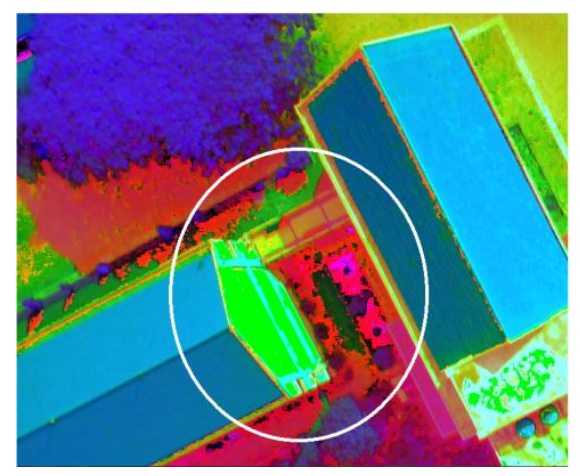

Gambar 25. Zoom area bayangan pada citra awal

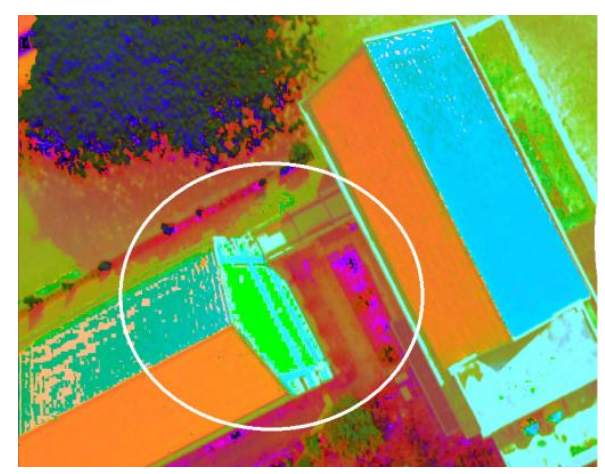

Gambar 26. Zoom area pada citra hasil enhancement

Pada gambar 26 terlihat adanya peningkatan visual pada area lingkaran putih apabila dibandingkan dengan gambar 25. Selain pada area bayang - bayang, transformasi warna HSL juga memiliki karakteristik peningkatan visual citra pada batas (edge) obyek. Hal tersebut dapat terlihat pada gambar 27 dan 28. 


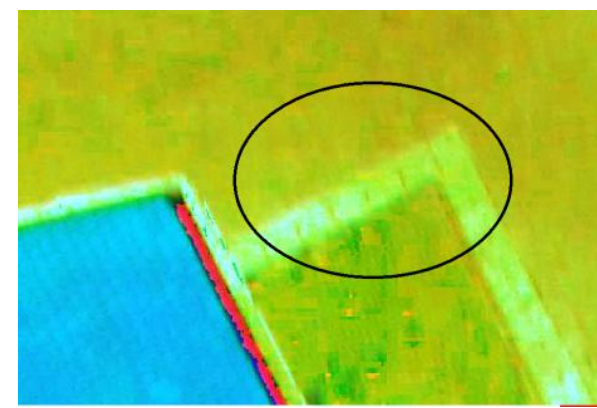

Gambar 27. Zoom area batas (edge) pada citra awal

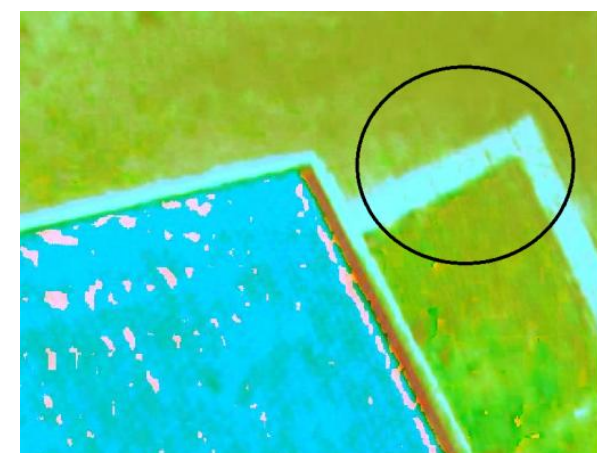

Gambar 28. Zoom area batas (edge) pada citra hasil enhancement

Pada area lingkaran hitam antara gambar 29 dan 30 terlihat adanya peningkatan visual pada batas (edge) area yang sebelumnya kurang jelas menjadi lebih jelas.

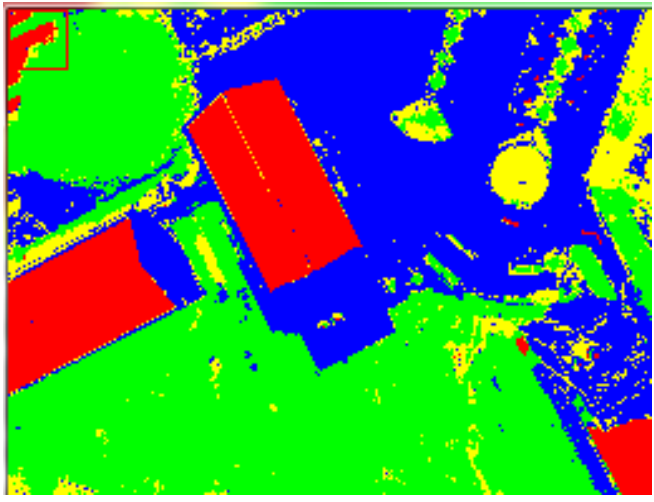

Gambar 29. Klasifikasi citra awal dg metode supervised-maximum likehood

Tabel 5. Statistik klasifikasi pada citra

\begin{tabular}{cccc}
\hline DN & Npts & Percent & Ket \\
\hline 1 & 1819834 & 13.001 & Atap Bangunan \\
2 & 5780772 & 41.300 & Vegetasi \\
3 & 5118977 & 36.572 & Semen Bangunan/Paving \\
4 & 1277217 & 9.125 & Pasir \\
\hline
\end{tabular}

Statistik yang didapat dari hasil klasifikasi menunjukkan bahwa foto udara yang digunakan memiliki hasil klasifikasi yaitu: vegetasi (41,3\%), atap bangunan $(13,0 \%)$, dan paving/semen
$(36,57 \%)$ dan permukaan yang tertutup pasir $(9,13 \%)$

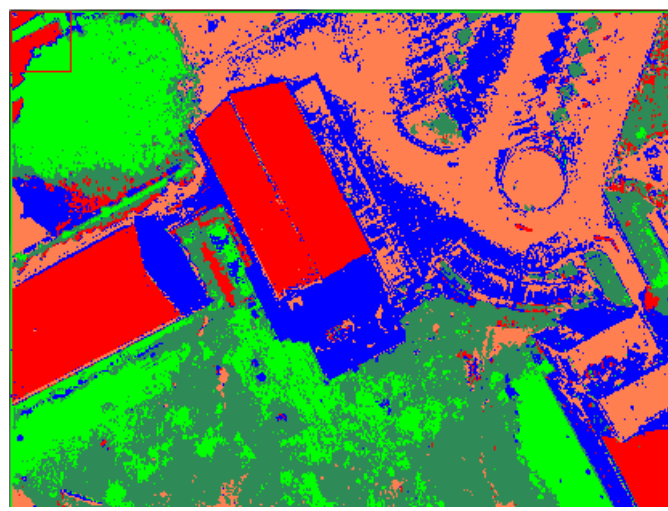

Gambar 30. Klasifikasi citra dg metode supervisedmaximum likehood

Tabel 6. Statistik klasifikasi pada citra

\begin{tabular}{cccc}
\hline DN & Npts & Percent & Ket \\
\hline 1 & 2008060 & 14.3466 & Atap Bangunan \\
2 & 2500663 & 17.8660 & Vegetasi rimbun \\
3 & 3336356 & 23.8366 & Vegetasi semak \\
4 & 3372920 & 24.0978 & Semen/Paving yang tertutup \\
5 & 2778801 & 19.8531 & pasir \\
\hline
\end{tabular}

Hasil statistik klasifikasi yang didapat dari citra hasil enhancement menunjukkan bahwa terdapat satu kelas tambahan dari kelas vegetasi yang terpecah menjadi vegetasi rimbun dan vegetasi semak.

\section{KESIMPULAN DAN SARAN}

\section{Kesimpulan}

Dari hasil penelitian dapat disimpulkan bahwa:

1. Apabila dibandingkan dengan nilai resolusi kamera metrik Rollei D7 yang memiliki nilai resolusi 4,31 mikron maka ditinjau dari segi nilai resolusi foto, kamera Canon Powershot A2200 yang memiliki nilai resolusi 1,8 mikron, berpeluang untuk digunakan dalam kepentingan fotogrametri jarak dekat.

2. Penggunaan gaussian stretching menyebabkan perubahan nilai mean pada tiap band yang cenderung membesar nilai digital numbernya yaitu :

$\mathrm{R}$ (115.2 menjadi 127.1)

G (111.4 menjadi 126.9)

B (93.9 menjadi 129.5)

3. Hal tersebut menunjukkan adanya peningkatan kecerahan pada citra dengan 
nilai digital number yang semakin membesar dan terlihat dari pola histogram yang menyerupai kurva gauss.

4. Dengan adanya proses penajaman (enhancement) dapat dihasilkan citra yang memiliki nilai informasi lebih dari sebelumnya terutama dari hal kontras warna.

\section{Saran}

1. Dibutuhkan penggunaan variasi metode contrast stretching agar didapat informasi yang berbeda sesuai kebutuhan.

2. Dibutuhkan adanya variasi pada waktu penggambilan data dengan wahana. Hal ini berkaitan dengan posisi matahari sehingga dapat mem-pengaruhi bayangan.

\section{DAFTAR PUSTAKA}

Atkinson. 1980. Developments in Close Range Photogrammetry-1. Applied Science Publishers. London

Atkinson. 1996. Close Range Photogrammetry and Machine Vision. Whittles Publishing. London

Scotland, UK. Chandler, Fryer J G and Jack A. 2000. Metric Capabilities Of Low-Cost Digital Cameras For Close Range Surface Measurement. Photogrammetric Record, 17(9\#), 200\#

Cahyono, A.B. dan Hapsari, H.H. 2008. Petunjuk Praktikum Fotogrametri 1. Laboratorium Fotogrametri. Program Studi Teknik Geomatika, FTSP, ITS.

Clark, A.F., J. C. Woods and O. Oechsle, 2010, A LowCost Airbone Platform For Ecological Monitoring, International Archives of Photogrammetry, Remote Sensing and Spatial Information Sciences, Vol. XXXVIII, Part 5, Commission V Symposium, Newcastle upon Tyne, UK. 2010.

Daniel Carneiro Silva . 2006 Non-Metric Digital Cameras Images Versus High Resolution Satellites Images In Regions With High Cloudiness. Shaping the Change XXIII FIG Congress Munich, Germany, October 8-13, 2006.

Daniel Carneiro da Silva and Ana Lúcia Bezerra Candeias. 2012. Color Restoration of Aerial Photographs. Federal University of Pernambuco Brazil

Peipe, J \& Stephanie, M. Perfomance Evaluation of A 5 Megapixel Digital Metric Camera For Use In Architectural Photogrammetry. ISPRS Vol XXXIV, Part 5/W12

S K Patra, Neeraj Mishra, R Chandrakanth, and R Ramachandran. 2002. I mage Quality Improvement through MTF Compensation - A Treatment to High Resolution Data. Advanced Data Processing Research Institute

203, Akbar Road, Manovikas Nagar Post, Secunderabad - 500009

Santoso, B. 2004a. Review Fotogrametri: Teknik Pengadaan Data \& Sistem Pemetaan. Program Magister Departemen Teknik Geodesi dan Geomatika. Institut Teknologi Bandung.

Fryer, J. G. 1985. Non-metric Photogrammetry and surveyors. Dept. of Civil Engineering and Surveying, University of Newcastle. N. S. W

Gonzales, R \& Woods, R. E. 2008. Digital Image Processing - An Adapted Version. Pearson Education Taiwan Ltd.

Grenzdörffer, G.J., A. Engelb, B. Teichertc, 2008, The Photogrammetric Potential Of Low-Cost UAVs In Foresty And Agriculture, The International Archives of the Photogrammetry, Remote Sensing and Spatial Information Sciences. Vol. XXXVII. Part B1. Beijing 2008.

Haralick, R.M. \& L.G. Shapiro (1992). Computer and Robot Vision Vol. II. Addison-Wesley Publishing Company, Sydney, 630p.

Karara, H. 1989. Non-Topographic Photogrammetry, 2nd Ed. Bethesda, MD.:American Society for Photogrammetry and Remote Sensing.

Pratt, William K. 2007. Digital QImage Processing (fourth edition).Wiley-Interscience.California

Williams, Tom L. 1999. The Optical Transfer Function of Imaging Systems.Institute of Physics Publishing Bristol. CRC Press. United Kingdom.

Williamson, James R. 2007. Close-Range Photogrammetry. 123 Photogrammetry. Pearland, Texas.

Wolf, P.R., 1983, Elements of Photogrammetry, 2nd edition, McGraw-Hill Book Company, USA

Wolf. P.R. 1993. Element of Photogrammetry, Dengan Interpretasi Foto Udara dan Penginderaan Jauh. Gadjah Mada University Press. http://focusnusantara.com/articles/menu_artikel.php. Diakses pada 28 Februari 2012 pukul 10.30 WIB 